(RESEARCH ARTICLE)

\title{
Phytochemistry, proximate and antioxidant properties of some indigenous leafy vegetables
}

\author{
Komlaga Gustav ${ }^{1,}{ }^{*}$ Gaveh Eli ${ }^{2}$, Jibira Yakubu ${ }^{1}$ and Mensah Merlin Lincoln Kwao ${ }^{1}$ \\ ${ }^{1}$ Faculty of Pharmacy and Pharmaceutical Sciences, Kwame Nkrumah University of Science and Technology (KNUST), \\ Kumasi, Ghana. \\ ${ }^{2}$ Faculty of Agriculture, KNUST, Kumasi, Ghana.
}

Publication history: Received on 20 July 2018; revised on 12 August 2019; accepted on 16 August 2019

Article DOI: https://doi.org/10.30574/wjarr.2019.3.1.0044

\begin{abstract}
The use of leafy vegetables in diet is a common practice among the people of the Northern ethnic groups of Ghana. In this study, a survey was conducted in the Bunkpurugu-Yunyoo district and Kanvilli of the Tamale Metropolis of the Northern Region of Ghana, to document the indigenous leafy vegetables routinely consumed as part of their alimentary culture. The phytochemical content, proximate composition and antioxidant properties of the plants cited were assessed. Nine leafy vegetables: Amaranthus cruentus, Hibiscus sabdariffa, Corchorus olitorius, Vernonia amygdalina, Phaseolus vulgaris, Ipomoea batatas, Adansonia digitata, Moringa oleifera and Annona reticulate were inventoried. These plants contained various groups of phytochemicals and were generally rich in carbohydrates, protein and fibre, but low in fat. They contain an appreciable amount of energy and also demonstrated good antioxidant activities. These characteristics of the vegetables suggested their usefulness in the maintenance of good health, which may also explains why these groups of Ghanaians in the Northern region are regarded as being very strong and healthy.
\end{abstract}

Keywords: Corchorus; Amygdalina; Moringa; Phaseolus; Adansonia

\section{Introduction}

Leafy vegetables (LV) are edible leaves often used as components of food [1]. They may consist of young, succulent stems, flowers and very young fruits together with the leaves [2].

Leafy vegetables play vital roles in human nutrition; serving as valuable sources of minerals, vitamins proteins and fibre for the majority of people. In developing countries, they are usually consumed, though, in relatively small amounts as side dishes [3, 4]. LV contain high amounts of dietary fibre, which helps to regulate the digestive system, manage the body's weight and improve health [5]. Aside these benefits, they have been strongly associated with good health and vision, reduced risks for some forms of cancer, stroke, diabetes, anaemia, gastric ulcer and also treat haemorrhoids, gallstones, obesity and constipation [6, 7]. They contribute to the reduction of malnutrition, especially in children, by their content of protein, vitamins, calories and minerals needed in diets [8, 9]. They also contain nonnutrient bioactive phytochemicals that have been reported to offer protection against cardiovascular diseases and other ailments [10]. They are, in addition, good sources of naturally occurring antioxidant compounds that inhibit or delay the oxidation of biomolecules by inhibiting the initiation or propagation of oxidizing chain reactions [11]. They thus protect body cells from damage caused by oxidative stress, which is linked to several chronic diseases such as cancers, diabetes mellitus, cardiovascular diseases and several neurodegenerative disorders in humans [11].

\footnotetext{
${ }^{*}$ Corresponding author

E-mail address: gustkomla@yahoo.com
} 
In Africa, leafy vegetables are increasingly being recognized as possible contributors of both micronutrients and bioactive compounds in diets [12]. However, Ghanaian diet comprises mainly of starchy roots, fruits and cereals [13]. Thus, according to the Food and Agricultural Organization [13], the dietary supply, though meets population energy requirement, is lower in proteins and lipids than recommended. The people from the northern part of the country however have consumed indigenous leafy vegetables (ILV) as a major component of their diet for generations, and this has become part of their culinary culture. This study inventoried ILV consumed in two communities in the Northern Region of Ghana and evaluated their phytochemical constituents, antioxidant properties and proximate composition to assess their nutritional value as well as other health benefits to the people.

\section{Material and methods}

\subsection{Study area}

The sites chosen for the survey were two communities: Bunkpurugu of the Bunkpurugu-Yunyoo District and Kanvilli of the Tamale Municipality, both in the Northern Region of Ghana (Fig. 1). This region has a rainfall, humidity, temperature and vegetation typical of the savannah zone.

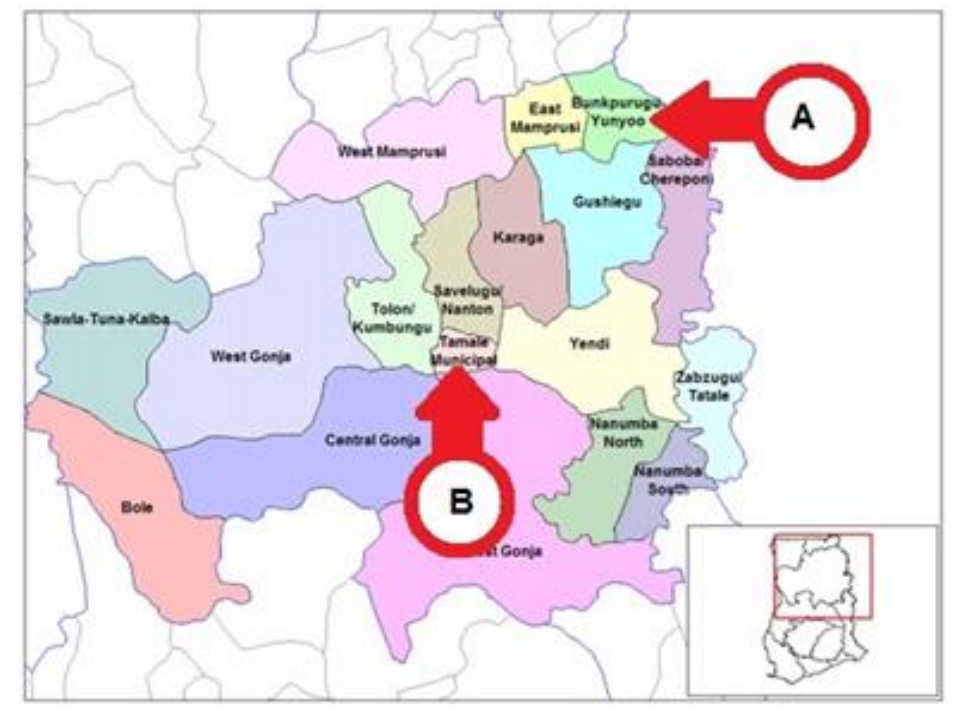

Figure 1 District map of the Northern Region of Ghana showing the study areas: (A) Bunkpurugu-Yunyoo District and

(B) Tamale Municipality. Inset: map of Ghana. Source: adapted from Wikimedia Creative Commons.

\subsection{Survey data collection}

Information on the vegetables was collected using a semi-structured validated questionnaire. Informants' consent was initially requested by administering informed consent forms following the explanation of the purpose of the study to the participants. The forms were filled and willingly signed or thumb-printed after which the questionnaires were administered. A total of 40 indigenes, 20 from each community, were interviewed using the prepared questionnaire as a guide. The respondents who were mostly farmers and residents within the communities for at least the past 10 years were interviewed. Demographic data of the respondents were first collected on their gender, age, ethnicity, religion, level of formal education, main occupation and duration of residence within the community. Questions related to the vegetables included respondent's knowledge of indigenous vegetables used in preparing food in the areas, purposes for using particular indigenous vegetables as part of their meals if any, frequency of their inclusion in diets, the form in which they are prepared, if the vegetables are also used as ornamental plants, their seasonal availability, whether grown or cultivated among others. Oral and informal interviews were conducted with both closed and open-ended questions. This was followed by collection of plant samples from their respective fields.

\subsection{Collection, processing and extraction of plant materials}

During the field visits, samples of the plant species were collected to prepare herbarium specimens and for further studies. The identities of the plant species were authenticated in the Departments of Horticulture, Food Science and Pharmacognosy, all of the Kwame Nkrumah University of Science and Technology (KNUST), Kumasi, Ghana. Specimens with voucher numbers were deposited at the Herbarium of the Department of Herbal Medicine, KNUST. 
The taxonomic validity of the plant names were checked using the plant database; www. thePlantList.org (accessed January, 2017). The remaining samples were cleared of all extraneous materials, air-dried at room temperature for about two weeks and milled into a coarse powder. The dried powdered plant materials were accordingly analysed as described below.

\subsection{Phytochemical screening}

Plant materials were tested for the presence of the various classes of secondary metabolites using standard methods $[14,15]$.

\subsection{Total antioxidant capacity using phosphate molybdenum (PM) assay}

The antioxidant assay was based on the reduction of molybdenum, $\mathrm{Mo}^{6+}$ to $\mathrm{Mo}^{5+}$ by the extracts and subsequent formation of a green phosphate molybdate $\left(\mathrm{Mo}^{5+}\right)$ complex in an acidic medium [16]. Ammonia molybdate (4 mM), disodium hydrogen phosphate $(28 \mathrm{mM})$ and sulphuric acid $(0.6 \mathrm{M})$ were added together in a beaker to prepare the reagent solution. Test tubes containing $1 \mathrm{ml}$ each of the different concentrations of the extract $(31.25-500 \mu \mathrm{g} / \mathrm{ml}) \mathrm{and}$ $3 \mathrm{ml}$ of the reagent were incubated at $95^{\circ} \mathrm{C}$ for 90 minutes. The process was repeated for concentrations of ascorbic acid as a standard $(3.125-100 \mu \mathrm{g} / \mathrm{ml})$. A blank solution was prepared by adding $1 \mathrm{ml}$ of methanol and the prepared reagent solution without the extract or standard. After the mixture had cooled to room temperature, the absorbance of the solutions were determined at $695 \mathrm{~nm}$ using the UV- visible spectrophotometer (Shimadzu, 1201, Japan). The experiment involving ascorbic acid was used to construct a calibration curve. The antioxidant capacity was expressed as $\mu \mathrm{g}$ of ascorbic acid equivalent (AAEq) per g of extract.

\subsection{2, 2 Diphenyl-picryl hydrazl (DPPH) radical scavenging assay}

Free radical scavenging activity was determined as described by Govindarajan et al. [17]. About $1 \mathrm{ml}$ aliquot each of the different concentrations of the extract (31.25- $500 \mu \mathrm{g} / \mathrm{ml}$ ) was added to a $3 \mathrm{ml}$ methanol solution of DPPH (20 $\mathrm{mg} / \mathrm{L}$ ) in a test tube. The reaction mixture was kept at room temperature in the dark for 30 minutes. A blank determination was done by adding $1 \mathrm{ml}$ aliquot of methanol and $3 \mathrm{ml}$ of DPPH solution together. The absorbance of the residual DPPH was determined at $517 \mathrm{~nm}$ in UV- visible spectrophotometer (Shimadzu, 1201, Japan). Ascorbic acid was used as the standard. Percentage DPPH inhibition was evaluated by comparing the test and blank solutions as follows:

$$
\% \text { DPPH inhibition }=1-\frac{A s}{A} \times 100
$$

Where $A$ is absorbance of the blank and $A s$ the absorbance of the test sample. The $\mathrm{IC}_{50}$ value (the concentration at $50 \%$ inhibition) was determined from the curve of percentage inhibition and log concentration.

\subsection{Total phenolic content}

The total phenolic content of the extracts was quantified using the Prussian Blue method [18] with some modification. Gallic acid was used as the reference substance. About $0.1 \mathrm{ml}$ of the various concentrations of the extract (31.25- 500 $\left.\mu \mathrm{g} \mathrm{ml}^{-1}\right)$ and gallic acid (3.125 -100 $\mathrm{g} \mathrm{ml}^{-1}$ ) were transferred into test tubes and diluted with 3 ml deionized water. To each test tube $1 \mathrm{ml}$ each of $\mathrm{K}_{3} \mathrm{Fe}(\mathrm{CN})_{6}(0.008 \mathrm{M})$ and $\mathrm{FeCl}_{3}(0.01 \mathrm{M})$ was added and left in the dark for 15 minutes. About $5 \mathrm{ml}$ of tragacanth was added to each test tube as a stabilizer and the absorbance of the solutions measured at $725 \mathrm{~nm}$ wavelength using the UV- visible spectrophotometer (Shimadzu, 1201, Japan). The concentrations of gallic acid were used to construct a calibration curve and the total phenol content in grams was determined as Gallic Acid Equivalent (GAEq $\mathrm{mg} / \mathrm{g}$ ) of the extract.

\subsection{Proximate analysis}

Proximate analysis of the samples was carried out according to the methods recommended by the Association of Official Analytical Chemists [19]. The analyses covered the seven proximate factors - moisture, protein, fat, ash, crude fibre, total carbohydrate and energy in fresh vegetables. Moisture content was determined by the oven drying method; ash by furnace dry ashing; crude fibre by an AOAC [19] method; crude protein by the Kjeldahl procedure; crude fat by Soxhlet extraction method and carbohydrate by calculation. Energy value of the samples were estimated in kilojoules per kg of sample by multiplying the protein, fat and carbohydrate percentages by the factors 16.7, 37.7 and 16.7, respectively, and then adding the results [20]. 


\subsubsection{Crude fat content}

Five grams ( $5 \mathrm{~g}$ ) of powdered plant sample was soxhlet extracted with petroleum ether into a flask previously dried at $110^{\circ} \mathrm{C}$ for $5 \mathrm{~min}$ and weighed. The extraction was carried out for about 4 hours after which the solvent was completely evaporated on water bath. The flask was placed in a desiccator and cooled to room temperature to remove any residual solvent. It was re-weighed and the percentage fat content of the sample calculated [19].

\subsubsection{Crude fiber content}

Crude fiber was estimated by acid-base digestion with $1.25 \% \mathrm{H}_{2} \mathrm{SO}_{4}$ and $1.25 \% \mathrm{NaOH}$ solutions [19]. The dried defatted residue was transferred into a dried clean digestion flask. About $200 \mathrm{ml}$ of $1.25 \% \mathrm{H}_{2} \mathrm{SO}_{4} \mathrm{Solution}$ was added and boiled for 30 min under reflux in the presence of an anti-foaming material. The boiled material was filtered and the residue washed with several portions of hot water until there was no trace of acid. The washed residue was put back into the flask and refluxed with $200 \mathrm{ml}$ of $1.25 \% \mathrm{NaOH}$ solution for another $30 \mathrm{~min}$. The content was filtered through a weighed Gooch crucible and thoroughly washed with hot water and then with about $15 \mathrm{ml}$ of $95 \%$ ethanol. The crucible with the content was dried at $110^{\circ} \mathrm{C}$ to constant weight. The material (in the crucible) was incinerated in a muffle furnace at $550^{\circ} \mathrm{C}$ for 30 min when the carbonaceous matter was consumed with only ash left. It was cooled in a desiccator and weighed. The loss in weight was recorded as crude fiber. The percentage crude fiber content was then calculated.

$\%$ crude fiber $=\frac{A-B}{C} \times 100$

Where $\mathrm{A}=$ weight of dry crucible and sample

$\mathrm{B}=$ weight of incinerated crucible and ash

$\mathrm{C}=$ weight of sample

\subsubsection{Crude protein content}

Approximately, $2 \mathrm{~g}$ of powdered plant sample was weighed into a $500 \mathrm{ml}$ digestion flask. This was hydrolyzed with 20 ml conc. $\mathrm{H}_{2} \mathrm{SO}_{4}$ containing selenium catalyst tablet and boiling chips under a fume cupboard into a clear solution. The cooled digest was diluted with distilled ammonia-free water to $100 \mathrm{ml}$ in a volumetric flask and used for the analysis. About $10 \mathrm{ml}$ of the hydrolysate was transferred into a clean Kjeldahl distillation flask and 90 ml distilled water followed by $20 \mathrm{ml}$ of the $40 \% \mathrm{NaOH}$ were added. The mixture was distilled onto $10 \mathrm{ml}$ of boric acid solution laced with a few drops of methyl red/methylene blue indicator. About $150 \mathrm{ml}$ of distillate was collected and titrated against $0.1 \mathrm{~N}$ $\mathrm{HCl}$ until the first appearance of pink colour was observed. A reagent blank with an equal volume of distilled water was titrated. The nitrogen content and therefore the protein content was calculated using the formulae below:

Total Nitrogen $\left(\mathrm{N}_{\mathrm{T}}\right)(\mathrm{g} / \mathrm{kg})=\frac{(\mathrm{Va}-\mathrm{Vb}) \mathrm{N}}{\text { Ws } x 10} \times 14.01$

Where $\mathrm{Va}=$ titre value of acid

$\mathrm{Vb}=$ titre value of blank

$\mathrm{N}=$ Normality of acid

Ws = weight of sample in grams

Therefore

\% Crude Protein $(\mathrm{CP})=$ Total Nitrogen $\left(\mathrm{N}_{\mathrm{T}}\right) \times 6.25$ (Protein factor) [19]

\subsubsection{Moisture content}

Approximately 5.0 g sample was weighed into a previously weighed moisture can. The sample in the can was dried in the oven at $105^{\circ} \mathrm{C}$ for $3 \mathrm{~h}$. It was cooled in a desiccator and weighed. It was again returned to the oven for further drying. Drying, cooling and weighing were done repeatedly at hourly interval until constant weight was achieved. The weight of moisture lost was calculated and expressed as a percentage of the weight of sample analysed [19]. It was given by the expression below:

Moisture content $=\frac{W f-W d}{W f} \times 100$

$\mathrm{Wf}=$ Fresh weight of sample

$\mathrm{Wd}=$ dried weight of sample 


\subsubsection{Ash content}

About $2 \mathrm{~g}$ of sample was weighed into a previously weighed porcelain crucible and heated to ash in a furnace at $550^{\circ} \mathrm{C}$. After complete combustion, the crucible was cooled in a desiccator and reweighed. The percentage ash content was then determined as below [19]:

$\%$ Ash $=\frac{W i-W f}{W s} \times 100$

Where Wi = weight of crucible with ash

$\mathrm{Wf}=$ weight of crucible only

Ws = weight of sample $(2 \mathrm{~g})$

\subsubsection{Carbohydrates content}

Carbohydrate content was determined after completing the analysis for ash, crude fibre, ether extract and crude protein. The percentage carbohydrate content was calculated adding the percentage values on dry matter basis of the analysed contents and subtracting them from $100 \%$ crude substance on dry matter basis [19].

Calculation

$\%$ Carbohydrate $=100 \%-(\%$ ash $+\%$ crude fibre $+\%$ crude fat $+\%$ protein $)$

\section{Results}

\subsection{Respondents' demographics}

The survey to document leafy vegetables consumed in the Northern Region of Ghana was carried out in 2 communities: Bunkpurugu of the Bunkpurugu-Yunyoo district and Kanvilli of Tamale municipality starting from May to July, 2016. The respondents were adults above 20 years and have been residents of the areas for more than 10 years. They were both females and males with the former constituting $62.5 \%$ of the participants. Indeed, in northern Ghana, it is the woman's chore to cook, and they often make culinary decisions on behalf of the whole family.

\subsection{Plant species cited as indigenous leafy vegetables}

The results showed the wide range of indigenous leafy vegetables which could be obtained either from the wild or cultivated farms. Nine (9) species belonging to 9 genera in 7 families were mentioned (Table 1.0; Fig. 2). The Malvaceae was the predominant family encountered and had 3 species mentioned; all other families had just a species each.

Table 1 Plant species use as indigenous leafy vegetables

\begin{tabular}{lll}
\hline Family & Scientific name & $\begin{array}{l}\text { Local name } \\
\text { (Dagbani/Mamprusi) }\end{array}$ \\
\hline Amaranthaceae & Amaranthus cruentus L. & Aleefu \\
Annonaceae & Annona reticulate L. & Dasaaluok \\
Asteraceae & Vernonia amygdalina Del. & Shuwaka \\
Convolvulaceae & Ipomoea batatas L.) Lam & Wulijo vari \\
Fabaceae & Phaseolus vulgaris L. & Bangli \\
Malvaceae & Hibiscus sabdariffa L & Braa \\
Malvaceae & Corchorus olitorius L. & Ayoyo \\
Malvaceae & Adansonia digitata L. & Kuuka \\
Moringaceae & Moringa oleifera Lam & Jangbaduuk \\
\hline
\end{tabular}




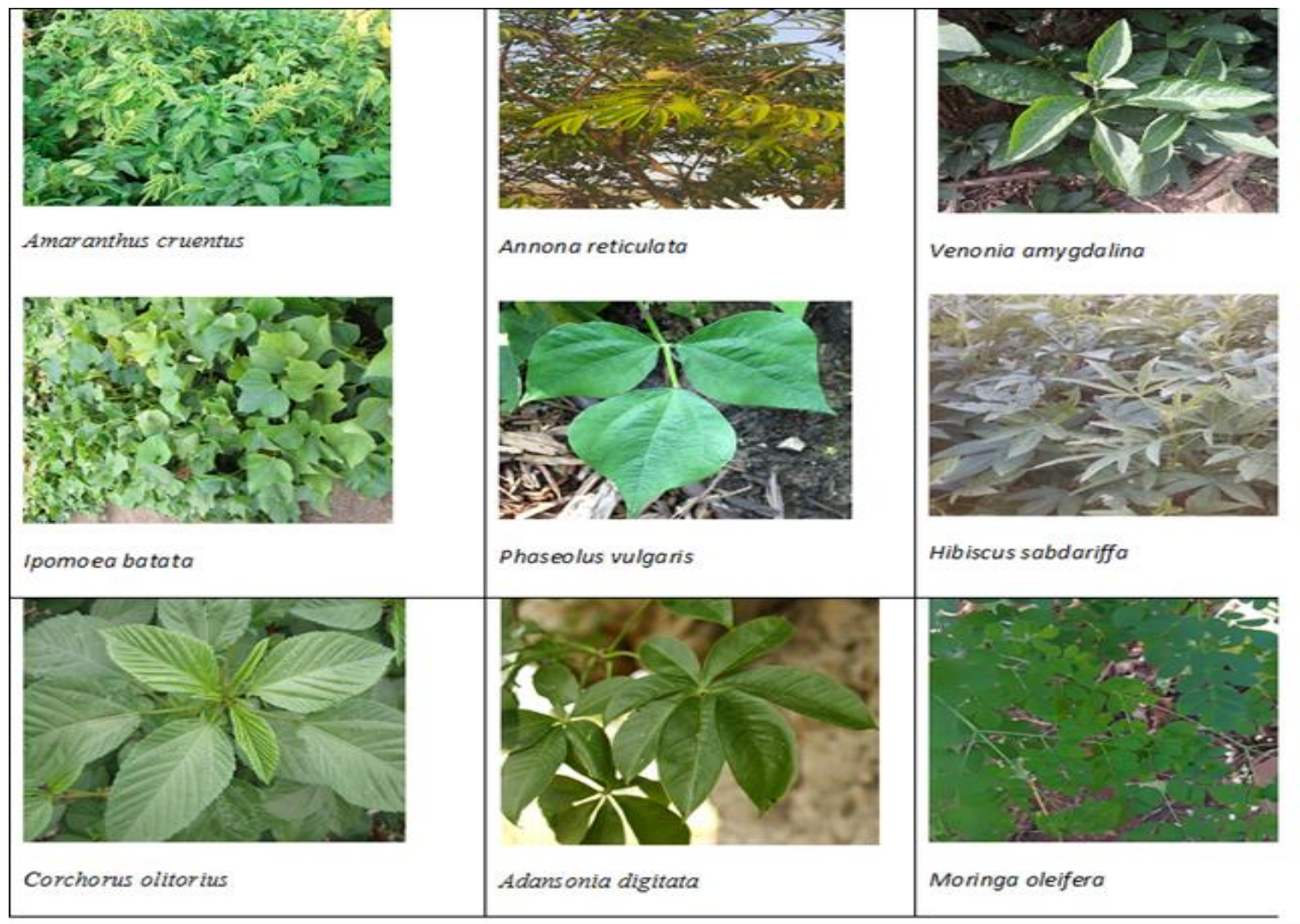

Figure 2 Photographs of indigenous leafy vegetables cited in the study

\subsection{Phytochemical constituents of cited plants}

The plant materials contained various phytoconstituents, which included tannins, flavonoids, glycosides, alkaloids, steroidal and non-steroidal saponins (Table 2.0). All plant materials tested positive for glycosides, tannins and flavonoids. V. amygdalina, C. olitorius and A. digitata contained all the phytoconstituents considered. All but $H$. sabdariffa contain saponins. These phytoconstituents may contribute variously to the health benefits of these leafy vegetables.

Table 2 Phytochemical constituents of the leafy vegetables

\begin{tabular}{lllllll}
\hline Scientific name & Tannins & Flavonoids & Reducing sugars & Alkaloids & Saponins & Sterols \\
\hline A. cruentus & + & + & + & - & + & + \\
A. reticulata & + & + & + & + & + & - \\
V. amygdalina & + & + & + & + & + & + \\
I. batatas & + & + & + & + & + & - \\
P. vulgaris & + & + & + & + & + & - \\
H. sabdariffa & + & + & + & + & + & + \\
C. olitorius & + & + & + & + & + & + \\
A. digitata & + & + & + & + & + & - \\
M. oleifera & + & + & + & & +
\end{tabular}

\subsection{Total antioxidant assay}

The total antioxidant capacity was expressed as Ascorbic acid equivalent of the sample. The value measures the equivalence of ascorbic acid contained in $1 \mathrm{~g}$ of the plant extract (Table 3.0) and is assumed to be proportional to the total antioxidant capacity of the sample. All the plants had appreciable antioxidant capacity with A. cruentus having 
the highest Ascorbic acid equivalence of $129.3 \pm 27.28 \mu \mathrm{g} / \mathrm{g}$ and hence a high antioxidant capacity. A. digitata had the least Ascorbic acid equivalence of $88.80 \pm 5.274 \mu \mathrm{g} / \mathrm{g}$ and hence a low antioxidant capacity.

The antioxidant property of these plants indicates their potential usefulness in reducing oxidative stress which contributes to many chronic diseases such as atherosclerosis, cancer, diabetes, rheumatoid arthritis, post-ischemic perfusion injury, myocardial infarction, cardiovascular diseases, chronic inflammation, stroke, septic shock, aging and other degenerative diseases in humans [21].

Table 3 Ascorbic acid equivalence for the various samples

\begin{tabular}{ll}
\hline Sample & $\begin{array}{l}\text { Ascorbic acid equivalence } \\
(\boldsymbol{\mu g} / \mathbf{g} \text { of extract) }\end{array}$ \\
\hline A. cruentus & $129.30 \pm 5.28$ \\
A. reticulata & $71.95 \pm 4.37$ \\
V. amygdalina & $99.47 \pm 4.19$ \\
I. batatas & $98.06 \pm 3.73$ \\
P. vulgaris & $97.35 \pm 1.36$ \\
H. sabdariffa & $108.50 \pm 2.55$ \\
C. olitorius & $103.40 \pm 5.18$ \\
A. digitata & $88.80 \pm 2.27$ \\
M. oleifera & $62.37 \pm 3.82$ \\
\hline
\end{tabular}

\subsubsection{Radical scavenging assay using 2, 2 diphenyl-picrylhydrazl (DPPH)}

The DPPH radical scavenging capacity was expressed as the $\mathrm{IC}_{50}$ value (Table 4.0), which is a measure of the amount of the sample needed to scavenge $50 \%$ of the free radical, DPPH. All the plants showed free radical scavenging properties with $P$. vulgaris having the lowest $\mathrm{IC}_{50}$ of $231.57 \pm 2.3 \mu \mathrm{g} \mathrm{ml}-1$ and hence the highest free radical scavenging capacity. $A$. digitata had the highest $\mathrm{IC}_{50}$ of $487.06 \pm 3.79 \mu \mathrm{g} \mathrm{ml}-1$ and hence the least free radical scavenging capacity. This thus confirms the low antioxidant capacity observed above for A. digitata. The free radical scavenging capacity contributes to the antioxidant property of the plants. High radical scavenging capacity may indicate a better antioxidant property of the plant.

Table 4 IC50 values of plant extracts and Ascorbic acid

\begin{tabular}{ll}
\hline Plant material & IC $50(\boldsymbol{\mu g} / \mathbf{m l})$ \\
\hline A. cruentus & $408.0 \pm 3.1$ \\
A. reticulata & $261.4 \pm 7.74$ \\
V. amygdalina & $438.74 \pm 6.94$ \\
I. batatas & $233.2 \pm 7.19$ \\
P. vulgaris & $231.57 \pm 2.3$ \\
H. sabdariffa & $438.06 \pm 4.65$ \\
C. olitorius & $288.0 \pm 2.76$ \\
A. digitata & $487.06 \pm 3.79$ \\
M. oleifera & $489.00 \pm 2.82$ \\
Ascorbic acid & $89.34 \pm 6.766$ \\
\hline
\end{tabular}

\subsection{Total phenolic content}

The total phenolic content was measured in terms of the Gallic acid equivalent of the sample expressed as the $\mu \mathrm{g}$ of Gallic acid equivalent in $1 \mathrm{~g}$ of plant extract as shown below (Table 5.0). The value is an indication of the amount in $\mu \mathrm{g}$ of the Gallic Acid Equivalent (GAEq) in $1 \mathrm{~g}$ of the plant extract. All the plants contained phenols and hence showed antioxidant properties. A. digitata having the highest GAEq of $438.4 \pm 7.91 \mu \mathrm{g} / \mathrm{g}$ and hence a high total phenol content 
and $H$. sabdariffa having the least GAEq of $35.0 \pm 46.55 \mu \mathrm{g} / \mathrm{g}$ and hence a low total phenol content. The presence of the phenols though may contribute to the antioxidant activity does not translate into significant antioxidant capacity.

Table 5 Gallic Acid Equivalence of samples

\begin{tabular}{ll}
\hline Sample & GAEq $(\boldsymbol{\mu g} / \mathbf{g}$ of extract $)$ \\
\hline A. cruentus & $131.2 \pm 1.63$ \\
A. reticulata & $396.5 \pm 44.03$ \\
V. amygdalina & $179.4 \pm 3.10$ \\
I. batatas & $287.1 \pm 0.024$ \\
P. vulgaris & $227.1 \pm 23.97$ \\
H. sabdariffa & $35.0 \pm 46.55$ \\
C. olitorius & $247.5 \pm 7.175$ \\
A. digitata & $438.4 \pm 7.91$ \\
M. oleifera & $163.4 \pm 17.12$ \\
\hline
\end{tabular}

\subsection{Proximate content of the cited vegetables}

The samples were analysed for moisture, ash, lipid, protein, carbohydrate and energy contents (Table 6.0). Among the 3 nutrients: carbohydrate, protein and fat, carbohydrate content was the highest and fat the lowest for all samples. The values indicates the nutritional importance of the vegetables to enhance growth, development and maintenance of health. A. reticulata and M. oleifera had the highest fibre content. This being an important factor for digestive health and regular bowel movements, can improve cholesterol and blood sugar levels and can assist in preventing some diseases such as diabetes, cardiovascular disease and bowel cancer [6,7]. These 2 vegetables would therefore be useful for digestion and good bowel movement and maintenance of health. The moisture content ranges from $5 \%$ in $A$. digitata and C. olitorius to $13 \%$ in I. batatas. Moisture is an important factor in food quality and preservation [22]. A. reticulata has the highest total ash content of 46.71 and V. amygdalina the lowest of 4.73\%. Total Ash/Minerals Ash refers to the inorganic residue remaining after complete oxidation of organic matter in a foodstuff. The ash content is a measure of the mineral content and other inorganic matter in food [23].

Table 6 Proximate composition of samples

\begin{tabular}{llllllll}
\hline Plant & Moisture (dry) & Ash & Fiber & Protein & Carbohydrate & Fat & Energy \\
\hline A. cruentus & 7 & 22.72 & 18.05 & 28 & 34.28 & 8 & 13416.76 \\
A. reticulata & 5.7 & 31.41 & 46.71 & 19.63 & 37.26 & 6 & 11762.63 \\
V. amygdalina & 10 & 4.73 & 18.78 & 30.13 & 51.14 & 4 & 15080.09 \\
I. batatas & 13 & 7.7 & 23.51 & 26.19 & 48.11 & 5 & 14293.10 \\
P. vulgaris & 8 & 11.61 & 22.05 & 31.69 & 47.7 & 1 & 13635.13 \\
H. sabdariffa & 11 & 6.25 & 19.09 & 32.03 & 48.69 & 2 & 14234.24 \\
C. olitorius & 5 & 21.15 & 20.77 & 24.69 & 45.16 & 4 & 13172.95 \\
A. digitata & 5 & 9.5 & 22.26 & 13.81 & 65.69 & 6 & 15538.50 \\
M. oleifera & 6 & 15.49 & 45.40 & 29.13 & 38.38 & 11 & 15421.17 \\
\hline
\end{tabular}

Energy was measured in KJ/Kg dry matter

\section{Discussion}

Indigenous leafy vegetables have been a common component of the diet of the people of the northern ethnic groups of Ghana. Various reasons were assigned for the consumption of this plant part in the communities. According to the participants in this study, the consumption of leafy vegetables is a culinary tradition, and some foods are not eaten without them. For example, corn flour meals such as "Tuo zaafi" is often if not always eaten with $C$. olitorius soup. Aside the cultural reason, the people also take leafy vegetable diets for their nutritional, health and therapeutic 
benefits. Some people consumed them just to maintain good health. H. sabdariffa for example is said to enhance bowel emptying, thus preventing constipation and unnecessary straining. V. amygdalina and M. oleifera may be routinely added to meals in order to manage chronic health conditions such as diabetes and hypertensive. Indeed, previous reports confirmed the antidiabetic and antihypertensive activities of V. amygdalina [24, 25] and M. oleifera [26, 27]. A. digitata is habitually used in the diet to maintain good oral health or to treat mouth sores. Of course, A. digitate is known to contain large amounts of ascorbic acid [28], which is important for good oral health [29]. A. reticulata for indigestion and constipation. Indeed other studies confirmed some of these activities [30-32]. The people cook the leafy vegetables in the preparation of soups and stews and these processes may have serious implications for the vitamins in the plant materials.

Due to the rapid urbanization of the northern region of Ghana, it is very necessary and important to document the indigenous leafy vegetables used in these areas and evaluate their nutritional and health properties; this would prevent the loss of such vital heritage with time.

The survey results demonstrated the rich flora of the Northern region of Ghana in terms of the availability of different types of indigenous leafy vegetables, which offer varieties and broaden the food base for the people. Interestingly, these leafy vegetables are obtained both from the wild and from cultivated farms in season. Unfortunately, some of these vegetables are annuals and are only available for a short period (about 3 months) of the year due to the long drought season that characterize the Northern part of Ghana. Leaves from perennial plants are not always available as these are shed during the drought. This condition may account for the high incidence of the reported undernourishment in that part of the country $[13,33]$ despite the rich dietary culture of the people.

\section{Conclusion}

The Northern Ghana is endowed with a rich biodiversity which include indigenous plants which serve as leafy vegetables and form part of the diet of the people. The vegetables are rich in antioxidants, the 3 classes of nutrients: carbohydrate, protein and fat. They also contain appreciable amounts of fibre and energy and are useful in the maintenance of good health. The regular consumption of the indigenous leafy vegetable in the diet may explain why these groups of Ghanaians are often regarded as very strong and healthy.

\section{Compliance with ethical standards}

\section{Acknowledgments}

We are grateful to the participants from Bunkpurugu of the Bunkpurugu-Yunyoo district and Kanvilli of Tamale municipality, Northern Region, who freely shared their knowledge and time with us during the study. We thank Mses Jemimah Afia Bamiyi Ntewusu and Ruby Edinam Tettey Tapang who collected the data as students on this project. We appreciate their contribution to the success of the study.

\section{Disclosure of conflict of interest}

All authors declare no conflict of interest

\section{Statement of informed consent}

Informed consent was obtained from all individual participants included in the study.

\section{References}

[1] Robinson D. (1990). Food biochemistry and nutritional value. Longman scientific and technical publisher, New York.

[2] Mepba H, Eboh L and Banigo D. (2007). Effects of processing treatments on the nutritive composition and consumer acceptance of some Nigerian edible leafy vegetables. African Journal of Food, Agriculture, Nutrition and Development, 7, 1-10.

[3] Iyaka YA. (2007). Concentration of copper and zinc in some fruits and vegetables commonly available in North Central zone of Nigeria. Electronic Journal of Environmental, Agricultural and Food Chemistry, 6, 2150-2154. 
[4] Jansen V, Rensburg WS, Venter SL, Netshiluvhi TR, Van Den Heever E, Vorster HJ and De Ronde JA. (2004). Role of indigenous leafy vegetables in combating hunger and malnutrition. South African Journal of Botany, 70, 5259.

[5] Anderson JW, Baird P, Davis RH, Ferreri S, Knudtson M, Koraym A, Waters V and Williams CL. (2009). Health benefits of dietary fiber. Nutrition Reviews, 67, 188-205.

[6] Dhingra D, Michael M, Rajput H and Patil RT. (2012). Dietary fibre in foods: a review. Journal of food science and technology, 49, 255-266.

[7] Slavin J and Lloyd B. (2012). Health benefits of fruits and vegetables. Advances in nutrition (Bethesda, Md), 3, 506-516.

[8] Ifon ET and Bassir 0. (1980). The nutritive value of some Nigerian leafy green vegetables-Part 2: The distribution of protein, carbohydrates (including ethanol-soluble simple sugars), crude fat, fibre and ash. Food Chemistry, 5, 231-235.

[9] Wehmeyer AS and Rose EF. (1983). Important indigenous plants used in the Transkei as food supplements. Bothalia, 14, 613-615.

[10] Van Duyn MAS and Pivonka E. (2000). Overview of the health benefits of fruit and vegetable consumption for the dietetics professional: Selected literature. Journal of the American Dietetic Association, 100, 1511-1521.

[11] Prior RL and Cao G. (2000). Antioxidant phytochemicals in fruits and vegetables: Diet and Health Implications. HORTSCIENCE, 35, 588.

[12] Smith FI. (2007). African leafy vegetables: their role in the World Health Organization's global fruit and vegetable initiative. African Journal of Food, Agriculture, Nutrition and Development, 7, 1-8.

[13] FAO. (2010). Nutrition country profiles: Ghana summary. In: Agric Consum Prot Dep.

[14] Evans WC. (2009). Trease And Evans' Pharmacognosy Textbook, 16th Editi. W.B. Saunders, Edinburgh, UK.

[15] Harborne JB. (1991). Phytochemical analysis: A Guide to Modern Techniques of Plant Analysis, 2nd ed. Chapman and hall. London

[16] Kasangana P, Haddad P and Stevanovic T. (2015). Study of polyphenol content and antioxidant capacity of Myrianthus Arboreus (Cecropiaceae) root bark extracts. Antioxidants, 4, 410-426.

[17] Govindarajan R, Rastogi S, Vijayakumar M, Shirwaikar A, Rawat AKS, Mehrotra S and Pushpangadan P. (2003). Studies on the antioxidant activities of Desmodium gangeticum. Biological \& pharmaceutical bulletin, 26, 14241427.

[18] Gupta C and Verma R. (2011). Visual estimation and spectrophotometric determination of tannin. Journal of Pharmaceutical Sciences and Research, 2, 189-196.

[19] Latimer GW. (2016). Official methods of analysis of AOAC international, 20 ${ }^{\text {th }}$ Ed. AOAC International, Maryland, USA.

[20] Eknayake S, Jansz ER and Nair BM. (1999). Proximate composition, mineral and amino acid content of mature Canavalia gladiata seeds. Food Chemistry, 66, 115-119.

[21] Uttara B, Singh AV, Zamboni P and Mahajan RT. (2009). Oxidative stress and neurodegenerative diseases: a review of upstream and downstream antioxidant therapeutic options. Current neuropharmacology, 7, 65-74.

[22] Pomeranz Y and Meloan CE. (1994). Determination of moisture. In: Food Anal. Springer US, Boston, MA, 575601.

[23] Sluiter A, Hames B, Ruiz R, Scarlata C, Sluiter J and Templeton D. (2005). Determination of ash in biomass: Laboratory Analytical Procedure (LAP).

[24] Nwaoguikpe R. (2010). The effect of extract of bitter leaf on blood glucose levels of diabetic rats. Int J Biol Chem Sci. 4(3), 721-729.

[25] Taiwo IA, Godwin P, Odeigah C, Jaja SI and Mojiminiyi FB. (2010). Cardiovascular effects of Vernonia amygdalina in rats and the implications for treatment of hypertension in diabetes. Researcher, 2(1), 76-79.

[26] Okorie C, Ajibeshin K, Sanyaolu A, Islam A, Lamech S, Mupepi K, Mupepi T, Oseni A, Oyeleke O and Abioye A. (2019). A review of the therapeutic benefits of Moringa oleifera in controlling high blood pressure (hypertension). Curr Tradit Med. 
[27] Villarruel-López A, López-de la Mora DA, Vázquez-Paulino OD, Puebla-Mora AG, Torres-Vitela MR, GuerreroQuiroz LA and Nuño K. (2018). Effect of Moringa oleifera consumption on diabetic rats. BMC complementary and alternative medicine, 18, 127.

[28] Rahul J, Jain MK, Singh SP, Kamal RK, Anuradha, Naz A, Gupta AK and Mrityunjay SK. (2015). Adansonia digitata L. (baobab): a review of traditional information and taxonomic description. Asian Pacific Journal of Tropical Biomedicine, 5, 79-84.

[29] Rathee DM, Bhoria DM and Kundu DR. (2011). Vitamin C and Oral Health: A Review. Indian Journal of Applied Research, 3, 462-463.

[30] Vigbedor BY, Osafo AS and Gyan BA. (2015). Ethnobotanical survey of plants used in the treatment of malaria in the Sekyere Central District of Ashanti Region of Ghana. International Journal of Novel Research in Life Sciences, 2, 17-25.

[31] Chavan SS, Shamkuwar PB, Damale MG and Pawar DP. (2014). A comprehensive review on Annona reticulata. International Journal of Pharmaceutical Science and Research, 5, 45-50.

[32] Taweerutchana R, Lumlerdkij N, Vannasaeng S, Akarasereenont P and Sriwijitkamol A. (2017). Effect of Moringa oleifera leaf capsules on glycemic control in therapy-naïve type 2 diabetes patients: A Randomized Placebo Controlled Study. Evidence-Based Complementary and Alternative Medicine, 1-6.

[33] The UNICEF and the INEI. (2008). Ghana multiple indicator cluster survey: Situation of children in Ghana Snapshots of Key Findings. 20.

\section{How to cite this article}

Komlaga G, Gaveh E, Jibira Y and Mensah MLK. (2019). Phytochemistry, proximate and antioxidant properties of some indigenous leafy vegetables. World Journal of Advanced Research and Reviews, 3(1), 12-22. 